\title{
Uji Reduksi Methylene Blue Pada Susu Segar di Kelompok Peternak Sapi Perah Dusun Pabyongan Kabupaten Tulungagung
}

\section{Reduction Test of Methylene Blue in Fresh Milk Dairy Farmers Group Pabyongan, Tulungagung}

\section{Andyanita Hanif Hermawati ${ }^{*}$ \\ Hariyanto'}

\section{Aulia Zahratul Husna'}

*ISTIKes Hutama Abdi Husada,

Tulungagung, Indonesia

2STIKes Hutama Abdi Husada,

Tulungagung, Indonesia

3STIKes Hutama Abdi Husada,

Tulungagung, Indonesia

*email: andya.nita@yahoo.com

\section{Kata Kunci:}

Susu Segar

Uji Reduksi

Methylene Blue I\%

Keywords:

Fresh Milk

Reduction Test

Methylene Blue I\%

\begin{abstract}
Abstrak
Susu adalah bahan makanan yang mempunyai gizi lengkap dan sempurna. Produk utama yaitu susu dihasilkan oleh sapi perah sebagai hewan ternak. Di Tulungagung ada beberapa daerah peternakan sapi perah diantaranya di dusun Pabyongan. Tujuan penelitian ini adalah menganalisa uji reduksi menggunakan methylene bluel\% pada susu segar di kelompok peternak sapi perah dusun Pabyongan Tulungagung. Penelitian ini merupakan desain deskriptif kualitatif dengan teknik Simple Random Sampling. Hasil penelitian ini menunjukkan bahwa dari total 10 sampel susu segar diketahui bahwa 9 sampel susu segar $(90 \%)$ memiliki uji reduksi baik dan sebanyak I sampel susu segar (10\%) memiliki uji reduksi buruk. Berdasarkan hasil penelitian diatas dapat disimpulkan bahwa $90 \%$ sampel susu segar di kelompok peternak sapi perah di dusun Pabyongan Pagerwojo memiliki uji reduksi yang baik. Hasil uji reduksi yang buruk disebabkan karena kondisi kandang kurang bersih, kondisi hewan sakit, kondisi peternak sakit, atau alat kurang bersih.
\end{abstract}

\begin{abstract}
Milk is a food that has complete and perfect nutrition. The main product produced by dairy cows as livestock. In Tulungagung there are several dairy farming areas, including the Pabyongan hamlet. The purpose of this study was to analyze the reduction test using methylene blue $1 \%$ in fresh milk in the dairy farmer group of Pabyongan Tulungagung hamlet. This research is a qualitative descriptive design with Simple Random Sampling technique. The results of this study indicate that from a total of 10 fresh milk samples, it is known that 9 fresh milk samples (90\%) have a good reduction test and I fresh milk sample (10\%) has a bad reduction test. Based on the results of the above research, it can be stated that $90 \%$ of the fresh milk samples from the dairy farmer group in Pabyongan Pagerwojo village have a good reduction test. Poor reduction test results are due to the condition of the cage is not clean, the condition of the animal is sick, the condition of the farmer is sick, or the equipment is not clean.
\end{abstract}

\section{PENDAHULUAN}

Susu adalah bahan makanan yang mempunyai gizi yang lengkap dan sempurna. Produk utama yaitu susu dihasilkan oleh sapi perah sebagai hewan ternak (Firman, 2010). Populasi sapi perah pada tahun 2015 jumlahnya mencapai 525.000 ekor di Indonesia. Jumlah populasi sapi perah di Provinsi Jawa Timur pada tahun 20II-20I5 mencapai 253.830 ekor (Dinas Petenakan, 20I5). Ada beberapa daerah yang memiliki peternakan sapi perah diantaranya di dusun Pabyongan
Tulungagung. Hal ini dibuktikan dengan sebagian besar warga di dusun Pabyungan Pagerwojo memiliki ternak sapi perah. Berdasarkan data yang diperoleh jumlah dari KUD Sri Wigati tahun 2016 sapi perah di kecamatan Pagerwojo \pm 6000 ekor dengan jumlah peternak mencapai \pm 2500 orang. Untuk diwilayah dusun Pabyongan jumlah peternak sapi perah \pm 50 orang.

Pada peternakan sapi perah banyak hal yang harus diperhatikan seperti kondisi kandang, peralatan 
untuk memerah susu dan menampung susu, dan kondisi fisik ternak, serta harus ada pengawasan dalam pemeliharaannya. Pada beberapa peternakan kandang yang bersih belum tentu tidak ada mikroorganismenya. Menggunakan air saja dalam membersihkan kandang masih memungkinkan tumbuhnya mikroorganisme dalam kandang tersebut. Pemerahan susu dengan cara manual juga dapat memicu tumbuhnya mikroorganisme dan pemerahan menggunakan alat mungkin juga dapat tumbuh mikroorganisme jika alat tersebut tidak bersih. Menampung hasil perahan di wadah terbuka dapat juga menyebabkan masuknya mikroorganisme dalam susu melalui udara.

Masyarakat sendiri kebanyakan sangat suka mengkonsumsi susu segar, tetapi kebanyakan masyarakat belum mengetahui bahwa di dalam susu segar banyak mengandung bakteri yang bisa menyebabkan timbulnya berbagai macam penyakit. Susu yang keluar dari kelenjar susu sapi perah akan terkontaminasi oleh bakteri yang disebabkan bakteri dari saluran puting (Aryani dan Suhartati, 2014). Kontaminasi ini disebabkan daerah puting basah dan lubang diujung puting tidak tertutup sehingga bakteri dapat tumbuh. Hal tersebut menjadi salah satu faktor pencemaran. Selain itu, ada beberapa hal yang mengakibatkan susu terkontaminasi diantaranya jika peralatan tidak dibersihkan secara maksimal terutama bagian yang kontak langsung dengan susu karena kotoran lainnya maupun sisa susu masih menempel. Daerah buangan feses juga dapat menjadi sumber kontaminasi ketika dilakukan pemerahan maka bakteri dapat masuk ke dalam susu melalui debu yang terbawa oleh angin jika masih berdekatan dengan kandang.

Kasus keracunan susu segar terjadi di Tulungagung pada 72 siswa SD, di Surabaya pada 73 karyawan Carefour, dan di Bandung pada 300 siswa SD pada September 2004. Tanggal 2 Juni 2009 di Cipayung Jakarta sejumlah 10 siswa SD dan di kabupaten Bandung pada 293 siswa setelah mengonsumsi susu segar mengalami mual. Keracunan menyerang tahun
2010 di SD Purbalingga pada semua siswa kelas 1-5 sejumlah II6 siswa dan di Kediri tahun 201। mengalami mual pada 3I siswa serta di Sumatra Utara akibat keracunan susu segar korban meninggal 2 orang (Lestari dkk, 20I2).

Pentingnya pengawasan terhadap keamanan susu segar yang dikonsumsi masyarakat akan berdampak pada kesehatan masyarakat karena kontaminasi susu segar dapat berakibat pada kejadian keracunan. Jika telah tercemar oleh mikroba dan tidak dikelola secara higienis maka susu yang dikonsumsi dapat menjadi sumber penularan penyakit. Mikroba patogen banyak dijumpai pada cemaran susu. Staphylococcus aureus dan Salmonella sp merupakan mikroba yang sudah teridentifikasi dan sering mencemari susu (Djaafar dkk, 2005). Berbagai infeksi lokal maupun sistemik dapat disebabkan oleh Staphylococcus aureus antara lain infeksi sendi dan tulang, infeksi pada valvula jantung serta pneumonia (Hermawati, 2016).

Mengetahui ada tidaknya kontaminasi pada susu segar sehingga susu tersebut layak untuk di konsumsi dibutuhkan sebuah uji. Uji reduksi merupakan salah satu cara tidak langsung untuk mengetahui jumlah bakteri di dalam susu sehingga mengetahui mutu dari susu. Uji reduksi mengamati kemampuan bakteri dalam susu untuk tumbuh menggunakan oksigen terlarut dengan cara menambahkan methylene blue ke dalam susu. Penambahan methylene blue akan tereduksi menjadi putih. Perubahan warna biru menjadi putih dianggap selesai jika kira-kira empat perlima dari contoh yang terdapat dalam tabung sebanyak $10 \mathrm{ml}$ telah berwarna putih yang disebut waktu reduksi (Aryani dan Suhartati, 20I4).

Tujuan dalam penelitian ini adalah untuk menganalisa uji reduksi pada susu segar menggunakan methylen blue di kelompok peternak sapi perah dusun Pabyongan Tulungagung. 


\section{METODE PENELITIAN}

Desain penelitian yaitu Deskriptif Kualitatif, untuk menganalisa uji reduksi menggunakan methylene blue pada susu segar di kelompok peternak sapi perah dusun Pabyongan Tulungagung. Sampel diambil dengan cara Simple random sampling. Sampel berjumlah 10 sampel susu segar di kelompok peternak dusun Pabyongan dan peneliti melakukan uji methylene blue di Laboratorium Patologi Klinik STIKes Hutama Abdi Husada Tulungagung.

Penelitian ini menggunakan alat yaitu pipet ukur Iml, tabung bertutup, gelas ukur, dan botol steril. Penelitian ini menggunakan bahan berupa susu segar dan methylen blue $1 \%$.

\section{Alur}

Pengambilan sampel : Disiapkan botol yang sudah disterilkan terlebih dahulu sebelumnya, kemudian untuk pengambilan sampel sebelum memerah harus dipastikan sudah mencuci tangan terlebih dahulu dan sebelum diperah puting susu harus dibersihkan menggunakan air hangat terlebih dahulu. Susu diperah ke dalam wadah botol yang sudah steril kemudian ditutup lalu dimasukkan sampel susu ke dalam coolbox yang berisi es.

Uji reduksi : Disiapkan alat dan bahan. Dimasukkan sampel susu sebanyak $10 \mathrm{ml}$ ke dalam tabung bertutup. Ditambahkan Iml methylen blue I\%, di homogenkan. Diinkubasi pada suhu $37^{\circ} \mathrm{C}$ dan dilakukan pengamatan terhadap perubahan warna setiap jamnya.

Rumus prosentase kualitas mikrobiologi baik :

Kualitas mikrobiologi baik = jumlah sampel kualitas mikrobiologi baik/total sampel $\times 100 \%$

Kualitas mikrobiologi buruk $=$ jumlah sampel kualitas mikrobiologi buruk/total sampel x 100\%

\section{HASIL DAN PEMBAHASAN}

\section{HASIL}

\section{A. Hasil Uji Konsistensi, Warna, dan Bau Susu Segar}

Tabel I. Distribusi Frekuensi Konsistensi, Warna, dan Bau Susu Susu Segar

\begin{tabular}{|c|c|c|c|c|c|c|c|}
\hline \multirow[b]{2}{*}{ No } & \multirow{2}{*}{$\begin{array}{l}\text { Sam } \\
\text { pel }\end{array}$} & \multicolumn{2}{|c|}{$\begin{array}{c}\text { Konsisten } \\
\text { si }\end{array}$} & Warna & Bau & \multicolumn{2}{|c|}{ Prosentase } \\
\hline & & Cair & $\begin{array}{c}\text { Agak } \\
\text { Kental }\end{array}$ & $\begin{array}{l}\text { Putih } \\
\text { Kekunin Putih } \\
\text { gan }\end{array}$ & $\begin{array}{l}\text { Khas Agak } \\
\text { Susu Busuk }\end{array}$ & Baik & Buruk \\
\hline I & $A$ & $\sqrt{ }$ & & $\sqrt{ }$ & $\sqrt{ }$ & $10 \%$ & - \\
\hline 2 & $B$ & $\sqrt{ }$ & & $\sqrt{ }$ & $\sqrt{ }$ & $10 \%$ & - \\
\hline 3 & $C$ & $\sqrt{ }$ & & $\sqrt{ }$ & $\sqrt{ }$ & $10 \%$ & - \\
\hline 4 & $\mathrm{D}$ & $\sqrt{ }$ & & $\sqrt{ }$ & $\sqrt{ }$ & $10 \%$ & - \\
\hline 5 & $E$ & - & $\sqrt{ }$ & $\sqrt{ }$ & $\sqrt{ }$ & - & $10 \%$ \\
\hline 6 & $F$ & $\sqrt{ }$ & & $\sqrt{ }$ & $\sqrt{ }$ & $10 \%$ & - \\
\hline 7 & $\mathrm{G}$ & $\sqrt{ }$ & & $\sqrt{ }$ & $\sqrt{ }$ & $10 \%$ & - \\
\hline 8 & $\mathrm{H}$ & $\sqrt{ }$ & & $\sqrt{ }$ & $\sqrt{ }$ & $10 \%$ & - \\
\hline 9 & $\mathrm{H}$ & $\sqrt{ }$ & & $\sqrt{ }$ & $\sqrt{ }$ & $10 \%$ & - \\
\hline 10 & 1 & $\sqrt{ }$ & & $\sqrt{ }$ & $\sqrt{ }$ & $10 \%$ & - \\
\hline & & & & Jumlah & & $90 \%$ & $10 \%$ \\
\hline
\end{tabular}

Berdasarkan Tabel I diketahui bahwa sebanyak 9 sampel susu segar (90\%) memiliki uji konsistensi cair, warna putih kekuningan, dan bau khas susu serta sebanyak I sampel susu segar (10\%) memiliki uji konsistensi agak kental, warna putih, dan bau agak busuk. Warni (2014) menyatakan bahwa kualitas susu segar yang baik tidak mengalami perubahan warna pada fisiknya. Menurut Mirdhayati (2008) jika pada fisik susu segar ada perubahan maka susu segar tersebut sudah terkontaminasi.

\section{B. Hasil Uji Reduksi Susu Segar}

Tabel II. Distribusi Frekuensi Uji Reduksi Susu Segar

\begin{tabular}{|c|c|c|c|c|c|c|}
\hline \multirow{2}{*}{ No } & \multirow{2}{*}{ Sampel } & \multirow{2}{*}{ Baik } & \multirow{2}{*}{ Buruk } & \multirow{2}{*}{ Frekwensi } & \multicolumn{2}{|c|}{ Prosentase } \\
\hline & & & & & Baik & Buruk \\
\hline $\mathrm{I}$ & $A$ & $\sqrt{ }$ & & $\mathrm{I}$ & $10 \%$ & - \\
\hline 2 & $\mathrm{~B}$ & $\sqrt{ }$ & & $\mathrm{I}$ & $10 \%$ & - \\
\hline 3 & C & $\sqrt{ }$ & & $\mathrm{I}$ & $10 \%$ & - \\
\hline 4 & $\mathrm{D}$ & $\sqrt{ }$ & & $\mathrm{I}$ & $10 \%$ & - \\
\hline 5 & $E$ & & $\sqrt{ }$ & $\mathrm{I}$ & - & $10 \%$ \\
\hline 6 & $\mathrm{~F}$ & $\sqrt{ }$ & & $\mathrm{I}$ & $10 \%$ & - \\
\hline 7 & $\mathrm{G}$ & $\sqrt{ }$ & & $\mathrm{I}$ & $10 \%$ & - \\
\hline 8 & $\mathrm{H}$ & $\sqrt{ }$ & & $\mathrm{I}$ & $10 \%$ & - \\
\hline 9 & $\mathrm{I}$ & $\sqrt{ }$ & & $\mathrm{I}$ & $10 \%$ & - \\
\hline \multirow[t]{2}{*}{10} & $\mathrm{~J}$ & $\sqrt{ }$ & & $\mathrm{I}$ & $10 \%$ & - \\
\hline & \multicolumn{4}{|c|}{ Jumlah } & $90 \%$ & $10 \%$ \\
\hline
\end{tabular}

Berdasarkan Tabel 2 diketahui jika sebanyak 9 sampel susu segar (90\%) memiliki hasil uji reduksi baik dan sebanyak I sampel susu segar (I0\%) memiliki uji reduksi buruk.

Hasil uji reduksi baik dikarenakan kondisi kandang di 9 peternakan tersebut telah memenuhi syarat yaitu kandang bersih dan pembuangan kotoran 
jauh dari kandang, sebelum diperah puting sapi dibersihkan terlebih dahulu menggunakan air hangat, pemberian makan memenuhi gizi dan kondisi sapi sehat. Mernurut Aryani dan Suhartati (2014) bahwa faktor yang mempengaruhi kualitas susu segar meliputi kondisi kandang, kesehatan hewan, pemberian makan yang cukup, dan kebersihan hewan tersebut. Hal tersebut menjadikan hasil dari pemerahan susu segar memiliki kualitas yang baik karena mengurangi kontaminasi. Peternak semakin sering membersihkan kandang maka kontaminasi dapat ditekan yang berasal dari kandang yang kotor (Utami, 20I4).

Kondisi kesehatan sapi dari 9 sampel susu segar dalam keadaan sehat tidak terinfeksi penyakit sehingga sampel susu segar yang dihasilkan memiliki hasil uji reduksi yang baik. Menurut Yusuf (20II) kualitas susu yang dihasilkan sangat dipengaruhi oleh kesehatan hewan sehingga susu dengan kualitas yang baik dihasilkan dari sapi yang sehat.

Pada 9 sampel susu segar pemberian makan pada ternak mencukupi gizi yang baik seperti rumput yang masih hijau, konsentrat, pemberian vitamin. Hal ini yang menjadikan kualitas dari susu segar yang dihasilkan menjadi baik. Menurut Siregar (200I) kualitas susu segar dipengaruhi oleh pakan. Selain itu, kebersihan hewan pada 9 sampel susu segar terjaga karena setiap akan dilakukan pemerahan karena setiap akan melakukan pemerahan sapi terlebih dahulu dimandikan atau dibersihkan 2 kali sehari. Hal itu yang menjadikan tingkat kontaminasi bakteri pada sampel susu segar sedikit. Navyanti (2015) menyatakan bahwa sapi perah perlu dimandikan setiap hari sampai bebas dari sisa makanan dan kotoran hewan yang menempel pada tubuhnya sehingga susu yang dihasilkan tidak terkontaminasi bakteri.

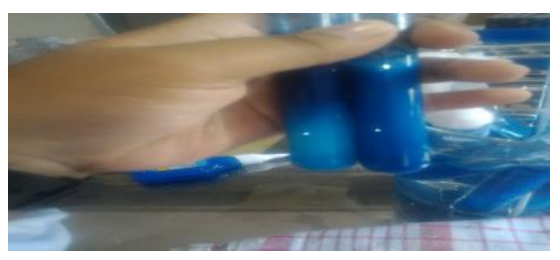

Gambar I. Hasil Uji Reduksi Methylene Blue
Berdasarkan Gambar I diketahui jika hasil uji reduksi baik memiliki ciri warna masih biru dan hasil uji reduksi buruk memiliki warna biru yang pudar menjadi putih.

Hasil uji reduksi buruk dikarenakan di peternakan tersebut kondisi kandang masih kurang memenuhi syarat yaitu kandang kurang bersih dan pembuangan kotoran yang masih di dekat kandang, kondisi hewan yang kurang baik, dalam mencuci puting sapi kurang bersih, dan kondisi pekerja kurang baik. $\mathrm{Hal}$ ini mungkin yang dapat menyebabkan ada kontaminasi bakteri pada susu segar yang dihasilkan karena kurang bersihnya kandang tersebut sehingga susu segar memiliki kualitas buruk. Hadiwijoyo (2009) menyatakan bahwa buruknya kualitas susu segar dapat dipengaruhi oleh kondisi kandang, kondisi hewan, kondisi peternak/pekerja, maupun kebersihan alat. Menurut Navyanti (2015) banyak kontaminasi baik berasal dari benda lainya seperti pasir, bulu, debu, dan sebagainya maupun bakteri disebabkan oleh kandang yang kotor.

Kondisi hewan juga kurang baik. Hal tersebut yang mungkin menyebabkan sampel susu segar terkontaminasi bakteri yang menyebabkan kualitas susu kurang baik. Navyanti (20I5) menyatakan bahwa susu yang mempunyai kandungan bakteri dalam jumlah banyak dihasilkan oleh sapi yang tidak sehat pada waktu diperah. Kondisi peternak/pekerja juga dalam keadaan kurang baik. Hal itu yang dapat menyebabkan adanya kontaminasi pada susu segar karena terkontaminasi dari peternak/pekerja tersebut. Navyanti (2015) menjelaskan pemerah harus dalam keadaan sehat saat memerah susu dan tidak mempunyai luka agar tidak mengkontaminasi susu. Peralatan yang kurang bersih juga mempengaruhi hasil reduksi yang buruk. Hal itu yang memungkinkan adanya kontaminasi bakteri pada sampel susu segar dikarenakan pencucian alat yang kurang bersih. Menurut Navyanti (2015) kontaminasi sering disebabkan karena wadah atau peralatan pada waktu 
pemerahan dalam keadaan kurang terjaga

kebersihannya atau kotor.

Dari pembahasan diatas dapat disimpulkan bahwa kualitas susu segar dapat dipengaruhi oleh kondisi kandang, kesehatan hewan, kondisi peternak, pemberian makan ternak, dan kebersihan alat yang digunakan untuk memerah. Dinas Peternakan hendaknya memberikan pendidikan dan pelatihan untuk mendapat kualitas susu segar yang baik kepada peternak dengan menjaga kondisi kandang tetap bersih, memberi makan ternak cukup, memastikan sapi dalam keadaan sehat tidak terinfeksi penyakit, dan selalu membersihkan alat yang digunakan untuk pemerahan sebelum dan sesudah digunakan.

\section{KESIMPULAN}

Berdasarkan hasil dan pembahasan didapatkan hasil uji reduksi pada susu segar menggunakan methylene blue diperoleh hasil $90 \%$ sampel susu segar memiliki uji reduksi baik dan $10 \%$ sampel susu segar memiliki uji reduksi buruk.

\section{DAFTAR PUSTAKA}

Aryani, dan Suhartati. 2014. Kategori Kulitas Susu Sapi Segar Secara Mikrobiologi Dipeternakan " $X$ " Cisurupan Garut. Tasikmalaya: Analis Kesehatan STIKes Bakti Tunas Husada Tasikmalaya

Azwar, A. 2005. Pengantar Ilmu Kesehatan Lingkungan. Jakarta: Penerbit Mutiara Sumber Widya Press

Buckle, K.A, dkk. 2009. Ilmu Pangan. Jakarta: UI Press

Dwidjoseptro, D. 2003. Dasar-Dasar Mikrobiologi. Jakarta: Djambatan

Darmaji. 2008. Informasi Susu Kambing Etawa. Buletin Pikiran Rakyat. Himpunan Studi Ternak Produktif. Jawa Tengah

Firman, Achmad. 2010. Agribisnis Sapi Perah. Bandung: Penerbit Widya Padjadjaran

Grahatika, Rio. 2009. Identifikasi dan Pemeriksaan Jumlah Total Bakteri Pada Susu Sapi di Kabupaten Karanganyar. Surakarta: Fakultas Farmasi Universitas Muhamadiyah Surakarta.
Hadiwiyoto, S. 2009. Pengujian Mutu Susu dan Hasil Olahan. Yogyakarta: Liberty

Hermawati, A.H. 2016. Aktivitas Kombinasi Madu Mangga Dan Susu Probiotik Sebagai Antibakteri Terhadap Staphylococcus aureus ATCC 6538 dan Escherichia coli ATCC 8739. Surabaya: Fakultas Kedokteran Universitas Airlangga Surabaya.

Husein, Umar. 20I3. Metode Penelitian untuk Skripsi dan Tesis. Jakarta: Rajawali

Jaser. 2000. Pembudidayaan Ternak Perah. Jakarta : CV Yasaguna

Jezezki, J.J. 2008. Progress in Basic Bacteriology of Milk. New York: Jhon Wiley and Sons

Khomsan, A. 2010. Pangan dan Gizi untuk Kesehatan. Jakarta: PT. Raja Grafindo Persada.

Lukman, D.W., Sudarwanto,M., Sanjaya,A.W., Purnawarman, T., Latif, L, dan Soejoedono, R.R. 2009. Higiene Pangan. Bagian Kesehatan Masyarakat Veteriner. Departemen IImu Penyakit Hewan dan Kesmavet. Fakultas Kedokteran Hewan IPB

Mirdhayati, I.J., Handoko, K.U.P. 2008. Mutu Susu Segar di UTP Ruminansia Besar Dinas Peternakan Kabupaten Kampar Provinsi Riau. Riau: Fakultas Peternakan dan Pertanian Universitas Islam Negeri Sultan Syarif Kasim

Muchtar, Ashry. 2006. Ilmu Produksi Ternak Perah. Surakarta: LPP UNS Press

Navyanti. 2015. Higene Sanitasi, Kualitas Fisik dan Bakteriologi Susu Sapi Segar Perusahaan Susu X di Surabaya. Surabaya: Fakultas Kesehatan Masyarakat Universitas Airlangga Surabaya

Notoatmodjo, Soekidjo. 20I0. Metodologi Penelitian Kesehatan. Jakarta : PT. Rineka Cipta

Notoatmodjo, Soekidjo. 2012. Promosi Kesehatan dan Perilaku Kesehatan. Jakarta: Rineka Cipta

Nurliyani, Rihastuti, Indratiningsih, dan Wahyuni Endang. 2008. Bahan Ajar Ilmu dan Teknologi Susu dan Telur. Yogyakarta: Fakultas Peternakan Universitas Gajah Mada Yogyakarta

Nurliyani, Rihastuti, Indratiningsih, dan Wahyuni Endang. 2012. Penanganan dan Pengolahan Susu Secara Sederhana. Yogyakarta: PT Citra Aji Pratama 
Prihadi, S. 2003. Menajeman Ternak Perah. Yogyakarta: Fakultas Peternakan Universitas Gajah Mada Yogyakarta

Rumentor, S.D. 2003. Stres Panas Pada Sapi Perah Laktasi. Makalah Falsafah Sains.Bogor: Program Pascasarjana Institut Pertanian Bogor

Rusmita. 20I I. Analisa Faktor-Faktor yang Mempengaruhi Produksi Susu Sapi FH (Fries Holland) pada Laktasi yang berbeda di UPT Ruminansia Besar Dinas Perternakan Kabupaten Kampar. Riau: Fakultas Pertanian dan Peternakan Universitas Islam Negri Sultan Syarif Kasim

Siregar. 200I. Penggemukan Sapi. Jakarta: Penebar Swadaya

Soejoedono, R.R., Sanjaya, A.W., Sudarwanto, M., Purnawarman, T., Lukman, D.W., Latif, H. 2005. Penuntun Praktikum Higiene Susu. Bogor: Fakultas Kedokteran Hewan Institut Pertanian Bogor

Soriah, W. 2010. Hubungan Variasai Pakan Terhadap Mutu Susus Segar di Desa Pasirbuncir Kecamatan Caringin Kabupaten Bogor. Bogor: Jurnal penyuluhan Pertanian. 5 (I) :67-77

Sudono. A.R.R, Fina dan B. Setyawan. 2003. Beternak Sapi Perah Secara Intensif. Jakarta: Argo Media Pustaka

Susilorini, T.E., Sawitri, Manik, Eirry, Muharlien. 2010. Budi Daya 22 Ternak Potensial. Jakarta. Penebar Swadaya

Utami. 2014. Kajian Kualitas Susu Sapi Perah PFH. Malang: Fakultas Peternakan Universitas Brawijaya Malang

Warni. 2014. Kualitas Susu Sapi di Kabupaten Sinjai dan Kaitan Dengan Infeksi Listeria Monocytogenes. Makassar: Fakultas Peternakan Universitas Hasanuddin Makassar

Yusuf. 20II. Tingkat Kontaminasi Escherichia Coli Pada Susu Segar di Kawasan Gunung Perak Kabupaten Sinjai. Makassar: Fakultas Peternakan Universitas Hasanuddin Makassar.

Yamamoto. 2004. Analisa Nutrisi Susu. Yogyakarta: Universitas Gajah Mada Press. 